\title{
Effectiveness of Plant Growth Regulators on Vegetative Growth of Strawberry cv. Camarosa
}

\author{
Vikash Kumar $^{1 *}$, Sanjay Sahay $^{1}$, Hidayatullah Mir ${ }^{1}$, Feza Ahmad ${ }^{1}$ and Kumari Rashmi \\ ${ }^{1}$ Department of Horticulture, Bihar Agricultural College, Bihar Agricultural University, \\ Sabour, Bhagalpur-813210, Bihar, India \\ ${ }^{2}$ Department of Plant Breeding and Genetics, Bihar Agricultural College, Bihar Agricultural \\ University, Sabour, Bhagalpur-813210, Bihar, India \\ *Corresponding author
}

\section{Keywords \\ Growth regulators, \\ Camarosa, \\ Naphthalene acetic acid (NAA) and Gibberellic acid $\left(\mathrm{GA}_{3}\right)$}

Article Info

Accepted:

10 June 2019

Available Online:

10 July 2019

\section{A B S T R A C T}

The field experiment was carried out at the permanent experimental field of horticulture garden, Bihar Agricultural College, Sabour, Bhagalpur during 2018-2019 for the Effectiveness of plant growth regulators on vegetative growth of strawberry cv. Camarosa. The experiment was laid out in Randomized Block Design with three replications having nine treatments such as: $T_{1}(\mathrm{GA} 3 @ 100$ ppm), T $(\mathrm{GA} 3 @ 150$ ppm), T 3 (GA3 @ 200 ppm), T (GA3 @ 250 ppm), T (NAA @ 100 ppm), T 6 (NAA @ 100 ppm), T 7 (NAA @ $100 \mathrm{ppm}$ ), $\mathrm{T}_{8}$ (NAA @ $100 \mathrm{ppm}$ ) and $\mathrm{T}_{9}$ (control) at 30, 60, 90 and 120 days after transplanting. Among the various concentration of plant growth regulators imposed that $250 \mathrm{ppm}$ of GA3 proved to best with respect to plant height $(28.54 \mathrm{~cm}$.$) , plant spread (39.00 \mathrm{~cm}$.), crown diameter $(42.68 \mathrm{~mm})$, petiole length $(12.53 \mathrm{~cm})$, no. of leaves per plant $(25.60)$, number of runner per plant (15.73), runner length $(23.27 \mathrm{~cm})$ and leaf area index $\left(36.52 \mathrm{~cm}^{2}\right)$. Hence, on the basis of overall findings of the present investigation stated that the increasing concentration of plant growth regulators which increase the vegetative growth of strawberry in cv. Camarosa.

\section{Introduction}

The cultivated strawberry (Fragaria $x$ ananassa Duch.; family Rosaceae) is a natural hybrid, derived from two North American species, Scarlet (Fragaria virginiana Duch.) and Chilean (Fragaria chiloensis Duch.). This is an octaploid $(2 \mathrm{n}=8 \mathrm{x}=56)$ developed in
France during the $17^{\text {th }}$ Century (Martinelli, 1992). It is one of the most fascinating delicious fruits due to its characteristic aroma, bright red in colour, juicy texture and nutritious fruits due to excellent source of vitamin $\mathrm{C}$, manganese, potassium as well as rich source of antioxidants which are consumed in large quantities, either fresh or in 
prepared foods, such as preserved fruit juice, pies, ice creams and milkshakes etc. among the soft fruits of the world (Kher et al., 2010). The strawberry is a typical short day and temperate climate fruit crops which are presently cultivated in many countries of world from the arctic to the tropics due to wider climatic as well as soil adaptation (Biswas et al., 2008) and also cultivated in nontraditional regions and different parts of India including sub-tropics and tropics region (Sharma and Sharma, 2004; Suga et al., 2013). In India, it is commercially grown in $\mathrm{J} \& \mathrm{~K}$, Maharashtra, Karnataka and Madhya Pradesh etc. Recently, strawberry's cultivation in northern India especially in Haryana, Punjab, Himachal Pradesh and parts of Uttar Pradesh is picking up fast due to availability of market in Delhi and another city. Strawberry being a vegetatively propagated plant and its commercial propagation through Runners. Runner is slender, prostrate branch with long internodes, creeping at the ground surface, rooting at the node and growing into a new plant.

The plant growth regulators like naphthalene acetic acid (NAA) and gibberellic acid $\left(\mathrm{GA}_{3}\right)$ have been found important to alter the growth, yield and quality parameters of strawberry fruit which enhances the plant resistance to biotic and abiotic stresses (Erdogan et al., 2016). $\mathrm{GA}_{3}$ progressively increases the plant height, canopy spread, leaf area, number of leaves, petiole length and induces stem elongation when applied exogenously to strawberry plants (Chovatia and Makhmale, 2017). Strawberry farmers are partially dependent upon the time and quantity of runner production of the plants. Early runner production which is prudent in both the cases, such as: runner's production and higher yield. The planting season, spacing and certain agrotechniques, like- application of nutrients, bio regulators, deblossoming, etc. are reported to exert significant influences on runner formation in strawberry. The quality and quantity of strawberry's runner plants can be regulated and optimized by adopting appropriate techniques. In the view of the potential commercial value of strawberry, Keeping the above facts in view, the present investigation was under taken to study the "Effectiveness of plant growth regulators on vegetative growth of strawberry cv. Camarosa."

\section{Materials and Methods}

The present investigation was carried out at the permanent research farm of Horticulture Garden, Bihar Agricultural College, Sabour, Bhagalpur (8702'42" E, 25015'40" N) at an altitude of $46 \mathrm{~m}$ above mean sea level in the heartof vast Indo-Gangatic plains of north India. The climateof this place is sub-tropical in nature which characterizedby dry summer, moderate rainfall and cold winter. January and February are usually thecoldest months whereas the mean temperature normallyfalls as low as $10.4^{\circ} \mathrm{C}$. The experiment was laid out in Randomized Block Design with three replications with spacing $40 \mathrm{~cm} \times 30 \mathrm{~cm}$ having nine treatments such as: $\mathrm{T}_{1}$ (GA3 @ 100 ppm), T2 (GA3 @ 150 ppm), T3 (GA3 @ 200 ppm), T4 (GA3 @250ppm), T5 (NAA @ 100 ppm), T 6 (NAA @ 100 ppm), T7 (NAA @ 100 ppm), $\mathrm{T}_{8}$ (NAA @ 100 ppm) and $\mathrm{T}_{9}$ (control) at 30, 60, 90 and 120 days after transplanting. The statistical analysis was carried out using ANOVA with Opstat software.

\section{Results and Discussion}

\section{Plant height (cm)}

The height of strawberry cv. Camarosa showed statistically significant variation with foliar spray of plant growth regulators and the height of tagged plants was measured with the help of a measuring scale from the ground 
level to the tip of the primary leaves of the plant and the average results were calculated on the basis of three plants in centimeters. The mean data pertaining to plant height in strawberry cv. Camarosa have been presented in Table 1 the scrutiny of the data revealed that the maximum plant height $(28.54 \mathrm{~cm})$ was recorded with foliar application of $\mathrm{T}_{4}\left(\mathrm{GA}_{3}\right.$ @ $250 \mathrm{ppm})$ followed by plant height $(27.67$ $\mathrm{cm}$.) with foliar application of $\mathrm{T}_{3}\left(\mathrm{GA}_{3} @ 200\right.$ ppm) and the minimum plant height (15.28 $\mathrm{cm}$ ) was obtained in $\mathrm{T}_{9}$ (control) which was statistically on equal footing with plant height $\left(16.00 \mathrm{~cm}\right.$.) with foliar application of $\mathrm{T}_{5}$ (NAA @ 100 ppm). The height of the plants during present investigation due to application of GA3 @250 ppm which increase the cell elongation and cell division (Rademabher, 2000). The above results are confined with work of Dwivedi (1987), Mohammed et al., (1990), Thakur et al., (2017).

\section{Plant spread (cm.)}

From the Table 1, the perusal data regarding to plant spread, the maximum width of the plant as measured from leaf tip to leaf tip at the maturity level of time. The maximum plant spread $(39 \mathrm{~cm})$ was found with foliar application of $\mathrm{GA}_{3} @ 250 \mathrm{ppm}$ followed by plant spread $(35.87 \mathrm{~cm}$.) with foliar application of $\mathrm{GA}_{3} @ 200$ ppm. While as, the minimum plant spread $(25.07 \mathrm{~cm}$.) was found with $\mathrm{T}_{9}$ (control) followed by plant spread (26.00 cm.) with foliar application of $\mathrm{T}_{5}$ (NAA@ 100 ppm). Due to application of plant growth regulators, which led to compatible environment in root zone which prevent the weed population. The sufficient soil moisture as well as abundant nutrients are available which regulated the growth of strawberry plant by causing cell elongation and cell division which increase length of petiole by application of $\mathrm{GA}_{3}$ and NAA. These results are in agreement with Palei et al., (2016) and Kumar et al., (2012b).

\section{Crown diameter (mm.)}

The data concerning to crown diameter for different concentration of plant growth regulators have been presented in Table 1 . The maximum crown diameter $(42.68 \mathrm{~mm}$.) was found with foliar application of $\mathrm{GA}_{3} @ 250$ ppm followed by crown diameter $(40.25 \mathrm{~mm}$.) with foliar application of $\mathrm{T}_{3}\left(\mathrm{GA}_{3} @ 200\right.$ ppm). But the minimum crown diameter was found in $\left(20.40 \mathrm{~mm}\right.$.) in $\mathrm{T}_{9}$ (control) followed by crown diameter $(30.13 \mathrm{~mm}$.) with foliar application of NAA @ 100 ppm. The crown diameter is the main fickle that has been used to determine the capability of the plants if the crown diameter length than $8.0 \mathrm{~mm}$ then it has been considered as a good vigor indicator plants as well as faster initial growth in strawberry cultivation (Hochmuth et al., 2001). The results are confined with work of Dale et al., (2006).

\section{Petiole length (cm.)}

The petiole is the stalk that supports a leaf in a plant which attaches with stem.Finding related with different concentration of plant growth regulators which has been presented in Table 1. The maximum length of petiole $(12.53 \mathrm{~cm}$.) was recorded with foliar application of $\mathrm{T}_{4}$ $\left(\mathrm{GA}_{3} @ 250 \mathrm{ppm}\right)$ but the minimum petiole length $(8.87 \mathrm{~cm})$ for $\mathrm{T}_{9}$ (control) followed by petiole length $(9.93 \mathrm{~cm}$.) with foliar application of $\mathrm{T}_{5}$ (NAA @ 100 ppm). The results agree with the observation of Palei et al., (2016).

\section{Number of leaves per plant}

The data concerning to number of leaves per plant have been given in Table 1. The maximum number of leaves (25.60) was found with foliar application of $\mathrm{T}_{4}\left(\mathrm{GA}_{3} @ 250\right.$ ppm) followed by number of leaves (22.80) with foliar application of $\mathrm{T}_{3}\left(\mathrm{GA}_{3} @ 200\right.$ ppm). 
Table.1 Effect of plant growth regulators on vegetative growth of strawberry cv. Camarosa

\begin{tabular}{|c|c|c|c|c|c|c|c|c|}
\hline Treatments & $\begin{array}{c}\text { Plant } \\
\text { height }\end{array}$ & $\begin{array}{c}\text { Plant } \\
\text { spread(cm) }\end{array}$ & $\begin{array}{c}\text { Crown } \\
\text { diameter } \\
\text { (cmm) }\end{array}$ & $\begin{array}{c}\text { Petiole } \\
\text { length } \\
\text { (cm) }\end{array}$ & $\begin{array}{c}\text { No. of } \\
\text { leaves } \\
\text { per } \\
\text { plant }\end{array}$ & $\begin{array}{c}\text { No. of } \\
\text { runner } \\
\text { per } \\
\text { plant }\end{array}$ & $\begin{array}{c}\text { Runner } \\
\text { length(cm) }\end{array}$ & $\begin{array}{c}\text { Leaf } \\
\text { area } \\
\text { Index } \\
\text { (cm } \mathbf{2}\end{array}$ \\
\hline $\mathbf{T}_{\mathbf{1}}$ & 22.40 & 31.67 & 30.00 & 9.93 & 19.00 & 12.60 & 20.93 & 27.07 \\
\hline $\mathbf{T}_{\mathbf{2}}$ & 26.30 & 34.07 & 39.93 & 10.63 & 21.53 & 13.60 & 21.27 & 29.00 \\
\hline $\mathbf{T}_{\mathbf{3}}$ & 27.67 & 35.87 & 40.25 & 11.60 & 22.80 & 14.27 & 22.36 & 33.62 \\
\hline $\mathbf{T}_{\mathbf{4}}$ & $\mathbf{2 8 . 5 4}$ & $\mathbf{3 9 . 0 0}$ & $\mathbf{4 2 . 6 8}$ & $\mathbf{1 2 . 5 3}$ & $\mathbf{2 5 . 6 0}$ & $\mathbf{1 5 . 7 3}$ & $\mathbf{2 3 . 2 7}$ & $\mathbf{3 6 . 5 2}$ \\
\hline $\mathbf{T}_{\mathbf{5}}$ & 16.00 & 26.00 & 30.13 & 9.80 & 15.07 & 6.00 & 16.87 & 14.00 \\
\hline $\mathbf{T}_{\mathbf{6}}$ & 17.00 & 27.00 & 30.33 & 10.93 & 16.93 & 7.47 & 17.97 & 16.07 \\
\hline $\mathbf{T}_{\mathbf{7}}$ & 17.53 & 28.07 & 30.53 & 11.47 & 18.67 & 9.20 & 18.8 & 18.56 \\
\hline $\mathbf{T}_{\mathbf{8}}$ & 18.67 & 29.00 & 30.60 & 12.00 & 21.00 & 10.20 & 19.83 & 20.35 \\
\hline $\mathbf{T}_{\mathbf{9}}$ & 15.28 & 25.07 & 20.40 & 8.87 & 19.00 & 5.67 & 15.03 & 15.00 \\
\hline Mean & $\mathbf{2 1 . 7 6}$ & $\mathbf{3 0 . 6 4}$ & $\mathbf{3 2 . 7 6}$ & $\mathbf{1 0 . 8 6}$ & $\mathbf{1 9 . 9 6}$ & $\mathbf{1 0 . 5 3}$ & $\mathbf{1 9 . 5 9}$ & $\mathbf{2 3 . 3 5}$ \\
\hline $\mathbf{C . V}_{\mathbf{V}}$ & 5.55 & 6.92 & 7.37 & 6.41 & 5.24 & 5.98 & 5.51 & 5.70 \\
\hline C.D @ 5\% & 2.04 & 3.70 & 4.21 & 1.21 & 1.82 & 1.09 & 1.88 & 2.32 \\
\hline $\begin{array}{c}\text { Lowest } \\
\text { Range }\end{array}$ & 15.28 & 25.07 & 20.40 & 8.87 & 15.07 & 5.67 & 15.03 & 14.00 \\
\hline Highest & 28.54 & 39.00 & 30.33 & 12.53 & 25.60 & 15.73 & 23.27 & 36.52 \\
\hline Range & & & & & & & & \\
\hline
\end{tabular}

While as, the minimum number of leaves (15.07) was found with foliar application of $\mathrm{T}_{5}$ (NAA@100 ppm) followed by number of leaves (16.93) with application of $\mathrm{T}_{6}$ (NAA @ $150 \mathrm{ppm})$. The number of leaves per plant which was highly significant with increasing concentration of plant growth regulators. The results are agreement with work of Lolaei et al., (2013), Vishal et al., (2016) and Kaur and Mirza (2018).

\section{Number of Runners per plant}

Finding related with number of runner per plant have been presented in Table 1. The maximum number of runner per plant (15.73) was found in $\mathrm{T}_{4}\left(\mathrm{GA}_{3} @ 250 \mathrm{ppm}\right)$ followed by number of runner per plant (14.27) in $\mathrm{T}_{3}$ $\left(\mathrm{GA}_{3} @ 200 \mathrm{ppm}\right)$ but the minimum runner per plant (5.67) was found in $\mathrm{T}_{9}$ (control) followed by number of runner per plant (6.00) in $\mathrm{T}_{5}$ (NAA @ 100ppm). The commercially propagation of strawberry by runners and it is the propagating materials for the cultivation of strawberry. The number of runners was increasing with high dose of $\mathrm{GA}_{3}$. Our results are confined with work of Lolaei et al., (2013) and Chovatia and Makhmale (2017).

\section{Runner length}

The data with respect to runner length under different treatments have been mentioned in Table 1. The maximum runner length $(23.27$ $\mathrm{cm}$.) was found in $\mathrm{T}_{4}\left(\mathrm{GA}_{3} @ 250 \mathrm{ppm}\right)$ followed by runner length $\left(22.36 \mathrm{~cm}\right.$.) in $\mathrm{T}_{3}$ $\left(\mathrm{GA}_{3} @ 200 \mathrm{ppm}\right)$ but the minimum runner length $(15.03 \mathrm{~cm})$ was found in $\mathrm{T}_{9}$ (control).

The runner length was increased with high concentration of plant growth regulators with favourable climatic factors which enhance the length of runner in strawberry. Our results were confined with Mohammed et al., (1990), Dwivedi et al., (2002) and Chovatia and Makhmale (2017). 


\section{Leaf area index}

The data concerning with the leaf area of different treatments have been given in Table 1. The maximum leaf area index $\left(36.52 \mathrm{~cm}^{2}\right)$ was found in $\mathrm{T}_{4}\left(\mathrm{GA}_{3} @ 250 \mathrm{ppm}\right)$ followed by leaf area $\left(33.62 \mathrm{~cm}^{2}\right)$ in $\mathrm{T}_{3}\left(\mathrm{GA}_{3} @ 200\right.$ ppm) but the minimum leaf area $\left(14.00 \mathrm{~cm}^{2}\right)$ was found in $\mathrm{T}_{5}$ (NAA @ 100ppm). The higher leaf area in these treatments might be attributed due to more available metabolites and their allocation to the above ground parts of the plants through roots. The application of gibberellic acid has the potential to control growth and flowering by reduced leaf area and induces earliness in strawberry. These findings are in line with Sharma and Singh (2009), Kumar and Manimegalai (2008) and Kaur and Mirza (2018).

From the results obtained during the present investigation with different treatments of different plant growth regulators on vegetative growth of strawberry cv. Camarosa, it can be concluded that plants treated with $\mathrm{GA}_{3} 250 \mathrm{ppm}$ which significantly increased the plant height $(\mathrm{cm}$.), plant spread $(\mathrm{cm}$.$) , crown diameter (\mathrm{mm})$, petiole length $(\mathrm{cm}$.), number of leaves per plant, number of runner per plant, runner length $(\mathrm{cm}$.) and leaf area index.

\section{Acknowledgements}

The authors are thankful to Chairman, Department of Horticulture, Bihar Agricultural College, Bihar Agricultural University, Sabour, India for providing all the required infrastructure and facilities for the present work.

\section{References}

Biswas, M.K., Islam, $\mathrm{R}$ and Hossain, $\mathrm{M}$. 2008. Micropropagation and field evaluation of strawberry in Bangladesh.
Journal of Agricultural Technology, 4(1): 167-82.

Chovatia, R.R.S., Makhmale, S.J. 2017. Effect of GA3, urea and $\mathrm{ZnSO}_{4}$ on growth and yield parameters of strawberry (Fragaria $x$ ananassa Duch.) cv. Sweet Charlie under protected condition. Advance Research Journal of crop improvement, 8 (1): 7074.

Dale, A., Elfving, D.C, Chandler, C.K. 2006. Benzyladenine and gibberellic acid increase runner production in strawberries. Journal of Horticulture Science, 31(7): 1190-1194.

Dwivedi, M.P. 1987. Effect of photoperiod and growth regulators on vegetative growth, flowering and yield of strawberry. Ph.D. Thesis, Dr. Y.S. Parmar University of Horticulture.

Dwivedi, M.P., Negi, K.S., Jindal, K.K., Rana, H.S. 2002. Influence of photoperiod and Bio regulators on vegetative growth of strawberry. Adv. Hort. \& Forestry, 7: 29-34.

Erdogan, U., Çakmakçi, R., Varmazyari, A., Turan, M., Erdogan, Y., Kitir, N. 2016. Role of inoculation with multi-trait rhizobacteria on strawberries under water deficit stress. Zemdirbyste, 103: 67-76.

Hochmuth, G., Chandler, C., Stanley, C., Legard, D., Duval, J., Waldo, E., Cantliffe, D., Bish, E. 2001. Containerized transplants for establishing strawberry crops in Florida. Hort. Science 37: 443-446.

Kaur, A. and Mirza, A. 2018. Corollary use of mulches and PGR'S on physicochemical properties of strawberry (Fragaria $\times$ ananassa) $\mathrm{cv}$. camarosa in polytunnel. Plant Archives, 18(2): 1745-1750.

Kher, R., Baba, J.A. and Bakshi. P. 2010. Influence of planting time and mulching material on growth and fruit yield of 
strawberry cv. Chandler. Indian Journal of Horticulture, 67(4):441-444.

Kumar, R., Bakshi, M. and Singh, D.B. 2012b. Influence of plant growth regulators on growth, yield and quality of strawberry (Fragaria $\times$ ananassa Duch.) under U.P. Sub tropics. The Asian Journal of Horticulture, 7(2):434436.

Kumar, R.S. and G. Manimegalai (2008). Effect of storage conditions on the shelf life of strawberry fruits. South Indian Horticulture, 46: 352-354.

Lolaei, A., Teymouri, N., Bemana, R., Kazempour, A. and Aminian, S. 2013. Effect of gibberellin on vegetative and sexual growth and fruit quality of strawberry (Fragaria $\times$ Ananassa Duch. cv. Selva and Qeen elisa). International Journal of Agriculture and Crop Sciences, 5(14): 1508-1513.

Martinelli, A. 1992. Micropropagation of strawberry (Fragaria spp.). In: HighTech and Micropropagation II. Springer, Berlin, Heidelberg. 354-370.

Palei, S., Das, A.K., Sahoo, A.K., Dash, D.K. and Swain, S. 2016. Influence of plant growth regulators on strawberry (Fragaria ananassa) cv. Chandler under Odisha condition. International Journal of Recent Scientific Research, 7(4): 9945-9948.

Rademabher, W. 2000. Growth retardants: Effect of gibberellins biosynthesis and other biosynthesis and other metabolic pathway. Annual review of plant physiology and plant molecular biology. 51: 501-531.

Sharma, R.R. and Singh, S. K. 1999. Strawberry cultivation-a highly remunerative farming enterprise. Agro India. 3: 29-31.

Sharma, V.P. and Sharma, R.R. 2004. The strawberry, ICAR, New Delhi, India, 2004.

Suga, H., Hirayama, Y., Morishima, M., Suzuki, T., Kageyama, K., and Hyakumachi, M. 2013. Development of PCR primers to identify Fusarium oxysporum f. sp. fragariae. Plant Dis. 97:619-625.

Thakur, Y., Chandel, J.S., Verma, P. 2017. Effect of plant growth regulators on growth, yield and fruit quality of strawberry (Fragaria $x$ ananassa Duch.) under protected conditions. Journal of Applied and Natural Science. 9(3):1676- 1681.

Vishal, V.C., Thippesha, D., Chethana, K., Maheshgowda, B. M., Veeresha B. G. and Basavraj, A. K. 2016. Effect of Various Growth Regulators on Vegetative parameters of strawberry (Fragaria $x$ ananassa Duch.) Cv. Sujatha, Research Journal Chemical and Environmental Sciences, 4 (4): 68-71.

\section{How to cite this article:}

Vikash Kumar, Sanjay Sahay, Hidayatullah Mir, Feza Ahmad and Kumari Rashmi. 2019. Effectiveness of Plant Growth Regulators on Vegetative Growth of Strawberry cv. Camarosa. Int.J.Curr.Microbiol.App.Sci. 8(07): 1259-1264. doi: https://doi.org/10.20546/ijcmas.2019.807.149 